\title{
Treatment Performance of an Autonomous Gray Water Treatment System (SAUTEG) with the Macrophytes Thalia geniculata
}

\author{
Franck Yovo ${ }^{1}$, Biaou Dimon ${ }^{1}$, Fidèle Suanon ${ }^{1,}$, Martin Aina ${ }^{2}$, Ignace Chabi Agani ${ }^{1}$, \\ Valentin Dieudonné Wotto ${ }^{1}$, Alexis Finagnon Crépin Togbe ${ }^{1}$ \\ ${ }^{1}$ Laboratory of Physical Chemistry, Faculty of Sciences and Techniques, University of Abomey-Calavi (LCP/FAST/UAC), Cotonou, \\ Republic of Benin \\ ${ }^{2}$ Laboratory of Technical Sciences of Water (LSTE), Cotonou, Republic of Benin
}

\section{Email address:}

yovofranck62@gmail.com (F. Yovo), fideldimon@yahoo.fr (B. Dimon), officielsuanon@yahoo.com (F. Suanon), marnickson@yahoo.fr (M. Aina), ignace.agani@gmail.com (I. C. Agani), bommow@yahoo.fr (V. D. Wotto), abobosfr@yahoo.fr (A. F. C. Togbe)

${ }^{*}$ Corresponding author

\section{To cite this article:}

Franck Yovo, Biaou Dimon, Fidèle Suanon, Martin Aina, Ignace Chabi Agani, Valentin Dieudonné Wotto, Alexis Finagnon Crépin Togbe. Treatment Performance of an Autonomous Gray Water Treatment System (SAUTEG) with the Macrophytes Thalia geniculata. American Journal of Environmental Protection. Vol. 5, No. 6, 2016, pp. 187-198. doi: 10.11648/j.ajep.20160506.16

Received: November 28, 2016; Accepted: December 8, 2016; Published: January 10, 2017

\begin{abstract}
The treatment of domestic wastewater and the improvement of our living environment is a matter of concern. Less costly methods are to be promoted because of the low financial power of the developing countries. In order to satisfy this requirement, here we have proposed an autonomous system for gray water treatment (SAUTEG) using the macrophytes Thalia geniculata plants. This system is composed of 75 plants $/ \mathrm{m}^{2}$ and purifying capacity EH equal to $8.7 \times 10^{-3}$ equivalent-inhabitant. Using this system, gray water (catch water: EGo and collectors of wastewater: ECo) were collected and processed (EGT and ECT) and physicochemical parameters of the gray water were determined according to the French standard. There was a significant reduction in organic pollution at the level of EGT and ECT respectively $\left(\mathrm{BOD}_{5}: 93.49 \%-99.04 \%\right.$, COD: $94.40 \%$ 98.25\%, MES: 99.99\% - 99,98\%), organoleptic parameters (color: 86.50\% - 84.63\%, Turb: 94.13\% - 88.61\%), trace metallic elements ( $\mathrm{Pb}: 24.52 \%-87.02 \%$, Cd: $11.84 \%-21.42 \%)$. There was also nutrients removal $\left(\mathrm{NO}_{3}^{-}: 96.49 \%-19.04 \%\right.$, NTK: $94.94 \%-100 \%$ and $\mathrm{PO}_{4}{ }^{3-}: 14.69 \%-55.02 \%$ ). The treated water was less turbid and lighter. There was a good performance of the system regarding biological parameters (E. coli: 100\%; Enterococci: $100 \%$ and thermo-tolerant Coli: $99.99 \%$ ). The values were close to those reported in the literature and some meet the standards of domestic wastewater treatment. Comparative study of the results revealed that the SAUTEG purified the waters from the collector better than the gray water. Thalia geniculata plants, in the system played an important role in the reduction of nitrates and lead in domestic wastewater. This system would therefore contribute to the improvement of the environment. We are looking forward to extending this study to other pollutants and to evaluating the saturation time of the system.
\end{abstract}

Keywords: Purification System, Thalia geniculata, Pollutants, Domestic Wastewater

\section{Introduction}

The major concern of mankind after the Second World War is the preservation of the human environment. Thus, the major challenge facing the world's political and economic decision-makers was that of economic and social development through poverty reduction and economic growth and the reduction of births [1]. The desire to achieve this goal has resulted in a high consumption of raw materials, a significant production of service goods, industrial products, 
pharmaceuticals, phytosanitary products... but also of discharges of all kinds with unpleasant consequences on the environment Air pollution, degradation of the living environment, etc.). These consequences have revealed the need to promote sustainable development, that is to say that it meets the needs of the present without compromising the ability of future generations to meet their own needs. As a result, several global fora examined the issue in all its dimensions and adopted a series of actions contained in the $21^{\text {th }}$ agenda and in the $21^{\text {th }}$ national agendas for the protection of the environment [2].

In the Republic of Benin, the constitution of 11 December 1990 institutionalized the protection of the environment. A Ministry of the Environment, Housing and Town Planning (MEHU) was therefore set up. Legislation, the framework law on the environment and a few implementing decrees have been adopted and promulgated [2]. Nevertheless, there are still serious failures in terms of sanitation. In the absence of sewage systems, wastewater treatment and treatment centers, well-organized solid waste management systems, the pollution of cities and countryside by wastewater is growing Discharges of solid, liquid and gaseous waste into the immediate environment into open gutters that release foulsmelling odors [3]. Some people allow themselves to throw the soiled waters of their sumps onto the tracks, making them impracticable for a long time, thus polluting the cities and countryside of the developing countries (Burundi, Guinea Konakry, Burkina Faso [4, 5]. Damage caused by these liquid wastes, such as the increase in waterborne diseases (cholera, diarrhea, vomiting, dysentery, gastrointestinal diseases, etc.) [6] and mosquitoes Of these waters their nests [7], make the developing countries think about the methods and techniques of managing these wastewater. The treatment of waste (liquid or solid) is based on several techniques including The Sahelian countries, where the thorny issue of the reuse of treated wastewater arises, resort to local materials (biological treatments) in the treatment of wastewater before any use [8]. For example, lagoon systems in Morocco [9], experienced pilot sewage treatment plants in Cameroon [10], Algeria [11] and several other countries have contributed A little to the treatment of gray water but present some deficiencies due to their limited purification efficiency, the exorbitant amount of their maintenance and then the bad dimensioning of the system. In developed countries where special emphasis has been placed on environmental sanitation through laws and decrees, communities subscribe to wastewater treatment companies [12]. In Benin, the difficulties encountered in relation to the effective management of domestic wastewater are governed by laws and regulations. The discomfort for the respect of its laws is the approaches. The basic approach is treatment and several treatment methods can be counted. Among these, the developed countries use the conventional methods based on mechanical devices (bar screening, degreaser, de-oiler, aerator, decanter, secondary basin and a tertiary treatment device) whose installation cost is high. The rise in treatment costs for which the price of the equivalent inhabitant varies from 100 cents US, the poor quality and inadequacy of certain wastewater treatment systems and the low income means of the populations brings the professionals Of treatment stations to make their choices on other techniques such as phytoremediation [13]. This less costly technique, based on the use of macrophytes to clean up the three components of the environment (water, soil and air), offers several advantages for developing countries [14] and some related weaknesses To the effect of macrophyte stress. Several macrophytes (water hyacinth, water lentils, water lettuce, reeds, bulrushes, poplars, irises, poplars, etc.) have already been tested by researchers [15-18]. In developing countries, the methods used are physical, chemical and especially biological techniques based on lagooning and the mechanisms of phytoremediation. The small means required for its installation leads several plant managers to use this technique for the treatment of domestic wastewater.

In our country, the Republic of Benin, where the inhabitants have a low income, we come across this study to propose to municipal officials, an original method of treatment of gray water based on the coupling of the planted pond to the techniques of phytoremediation. In our case, we have detected a macrophyte, Thalia geniculata, which, apart from its multiple functions, plays the secondary role in the system to remove nutrients and trace elements from domestic wastewater. It is in order to better reduce the gray water pollutants that the present work is examining the implementation of an Autonomous Gray Water Treatment System (SAUTEG) in order to evaluate its purification performance. Attainment of this objective led the study to dimension the system from the design parameters, to determine the physicochemical parameters of the treated water and then to compare the purification yields with those of the literature.

\section{Materials and Methods}

\subsection{Materials}

The present work was conducted at the Physical Chemistry Laboratory of the University of Abomey Calavi. The dimensioned SAUTEG was installed behind the Laboratory of Physical Chemistry at the University of Abomey Calavi (South Benin). This area is characterized by a subequatorial climate with two rainy seasons (April-July, OctoberNovember) and two dry seasons (August-September, December-March). The average rainfall in the commune of Abomey Calavi is $1200 \mathrm{~mm} /$ year and its mean temperature varies between $24^{\circ} \mathrm{C}$ and $32^{\circ} \mathrm{C}$. The wastewater samples were taken in a1.5 L polyethylene bottles, previously washed and rinsed; and sterilized plastic bags. Collector XX and a sump located in Agla district (located in the $13^{\text {th }}$ and $12^{\text {th }}$ districts of the commune of Cotonou, respectively) were the sources of gray water collection (Figure 1). 


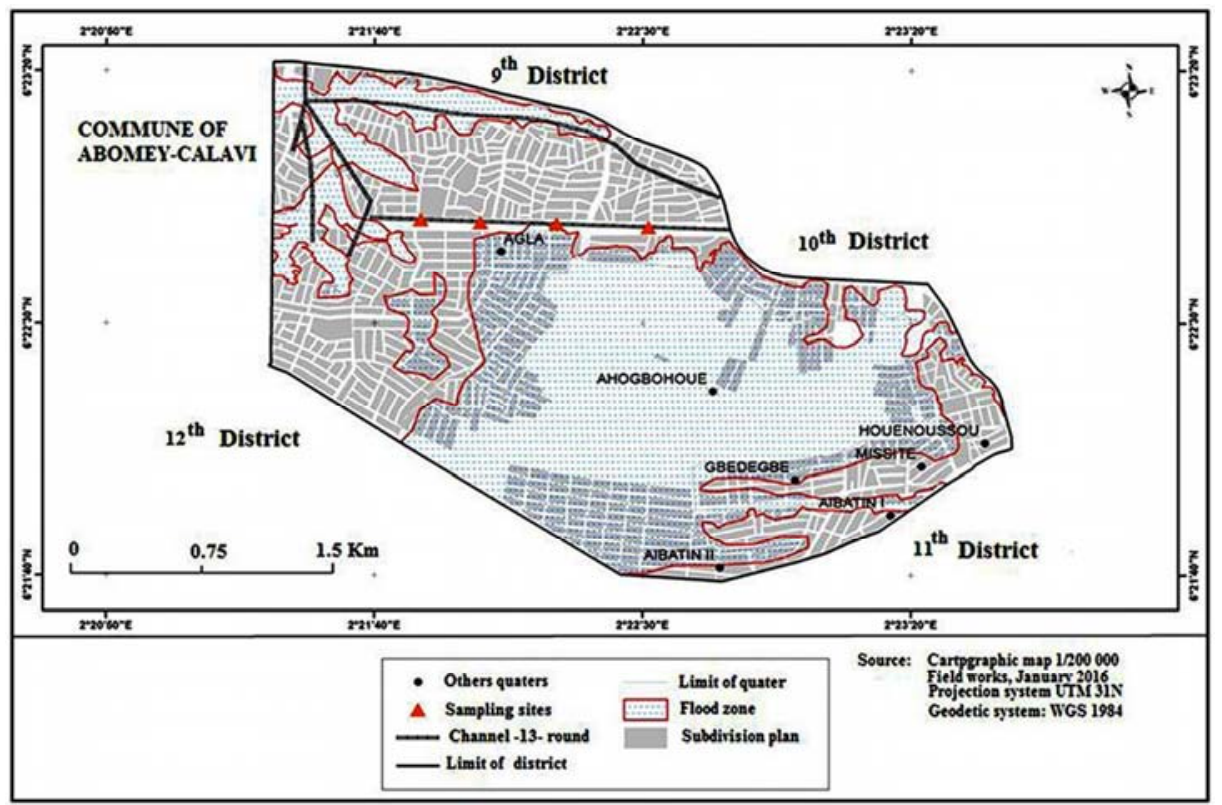

Figure 1. Map showing the collector of Agla then the $12^{\text {th }}$ and $13^{\text {th }}$ districts of the commune of Cotonou (South Benin).

The sampling technique was based on the approved by Ifremer in 2005. The Agla water collector drains rainwater and water from human activities. Collector wastewater (ECo) is often used for truck washing and gardening. The sump collects the water from showers and kitchens. The waters of the sump (EGo) are poured on tracks or thrown into open gutters. The samples of water collected and treated by the SAUTEG system are found in the Figure 2. The gray water treatment system (SAUTEG) (Figure 3) was designed and used to reduce the various pollutants of EGo and ECo.

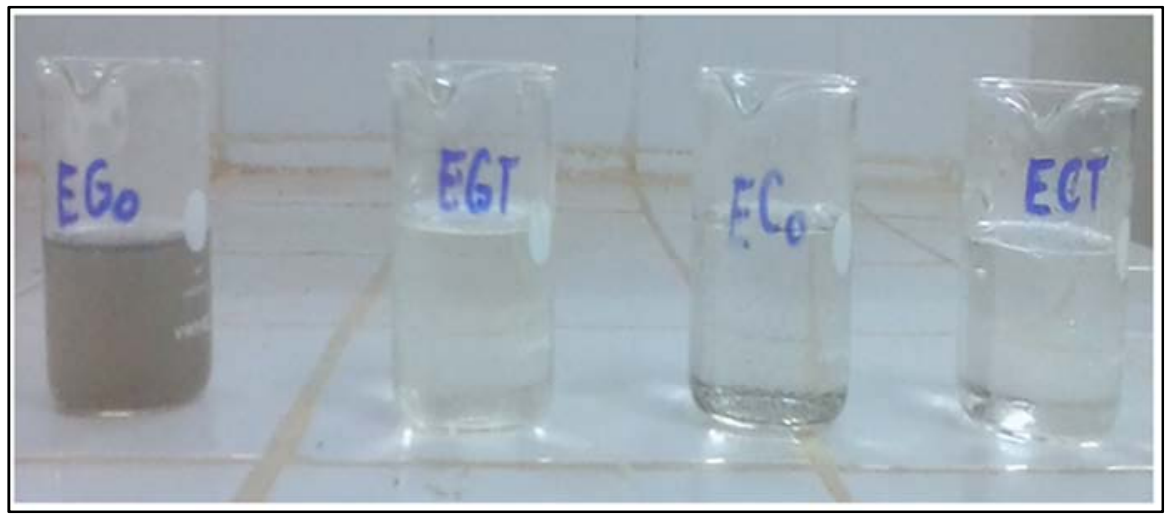

Figure 2. Samples of water collected and treated by the SAUTEG system.

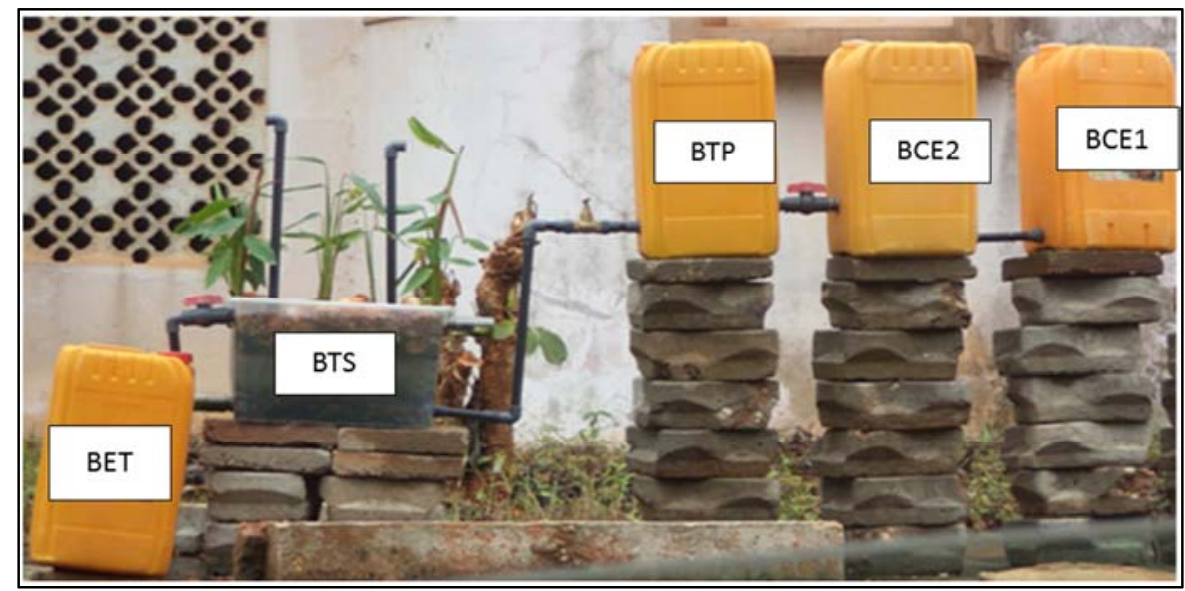

Figure 3. Autonomous Gray Water Treatment System (SAUTEG). 


\subsection{Analytical Methods}

\subsubsection{Physicochemical Parameters}

Samples analysis was performed at Laboratory of Physical Chemistry (LCP) of the University of Abomey Calavi on one hand and the Laboratory of Management, Treatment and Recovery of Waste (LGTVD) of The Faculty of Science and Technology of the University of Lomé on the other hand. The physicochemical parameters of wastewater such as: temperature $(\mathrm{T})$, conductivity $(\chi)$, total dissolved solids (TDS) were measured using the multi parameter Hanna waterproof Combo according to the standard NF EN 27888. The $\mathrm{pH}$ was measured by the electrochemical method with the Mettler Toledo $\mathrm{pH}$ meter equipped with a LE 409 probe (NFT 90-008) and color (Coul) by the APHA PlatinumCobalt method. The turbidity (Turb) was determined by the DR/890 colorimeter according to NFT standard 90-033 and the redox potential (Eh) was measured with the WTW $\mathrm{pH} / \mathrm{EH} 340 \mathrm{i}$ according to the standard NF EN 27888. The dissolved oxygen $\left(\mathrm{O}_{2}\right.$ dissolved) was measured with the WTW pH/O2 Innolab 740i according to NF EN 25814.

\subsubsection{Pollution Parameters}

Suspended solid matters (MES) were measured by filtration according to the standard NF EN 90-105-1. Orthophosphates $\left(\mathrm{PO}_{4}{ }^{3-}\right)$, nitrates $\left(\mathrm{NO}_{3}{ }^{-}\right)$and total nitrogen Kjeldahl (NTK) were assayed according to French standards (NF EN T90-023; NF EN ISO 13395 and NFT 90-110, respectively) with the HACH-DR spectrophotometer 2800 programmed at waves lengths 280, 507 and $490 \mathrm{~nm}$, respectively. $\mathrm{COD}$ and $\mathrm{BOD}_{5}$ were determined by volumetric methods according to NFT 90-101 and NFT 90-103, respectively. The trace metallic elements $(\mathrm{Cd}$ and $\mathrm{Pb})$ were determined using the Thermo-fisher flame atomic absorption spectrophotometer (F-SAA) according to the standards (NF EN 12497 and NF EN 12498). The biological parameters (fecal enterococci and fecal coliforms) were determined by enumeration in SLANETZ medium $\left(24 \mathrm{~h}-48 \mathrm{~h}\right.$ at $\left.37^{\circ} \mathrm{C}\right)$; by the method based on agar incorporation according to NF-
90416 standard. Escherichia coli was counted according to standard NF-08-05 with Rapid-E coli medium $\left(24 \mathrm{~h}\right.$ at $\left.44^{\circ} \mathrm{C}\right)$.

\section{Results and Discussion}

\subsection{Sizing}

\subsubsection{Methods of Designing Wastewater Basins}

Several methods and sizing parameters visited to determine the capacities of the basins' system can be found in a table in the appendix of the document (Table A2). The table summarizes the methods used [19, 20], based on volume loading, residence or retention time, flow and then temperature of the treatment medium to size Systems. The Canadian, World Bank, British and J.BROOMER methods were based on the useful volumes, the number of users and the parameters mentioned above. From the useful volume the dimensions of the basin can be known. As for the methods of lagooning, one notes the use of the purifying capacity $(\mathrm{EH})$ which is expressed in inhabitant equivalent. In Wallonia, $1 \mathrm{EH}=60 \mathrm{~g}$ of $\mathrm{BOD}_{5} /$ day $=120 \mathrm{~L}$; and thus depends on the volume load that can be absorbed by the basin. The calculation of this parameter is based on those evoked by other methods. In addition, the design of the filter ponds takes into account the $\mathrm{EH}$, the working volume, the volume loading, the flow rate and in addition to the density of the macrophytes, the thickness of the gravel layers, the water level, the surface of the basin filter and then its difference in level between the arrival of the waste water and its discharge. These parameters were useful for the dimensioning of our system.

\subsubsection{Sizing of the Autonomous Gray Water Treatment System (SAUTEG)}

The dimensioning of the SAUTEG treatment system was based on the various parameters and the different sizing methods above-mentioned. The various calculated sizing parameters are recorded in the table below (Table 1).

Table 1. System dimensioning parameters.

\begin{tabular}{|c|c|c|c|c|c|c|c|}
\hline $\begin{array}{l}\text { Parameters } \\
\text { Basins }\end{array}$ & $\begin{array}{l}\text { Volume useful } \\
\text { (Vu in } L)\end{array}$ & $\begin{array}{l}\text { Retention time } \\
\text { (Ts in min) }\end{array}$ & $\begin{array}{l}\text { Flow rate }(Q \\
\text { in } L / m i n)\end{array}$ & $\begin{array}{l}\text { Organic Charge } \\
(\lambda \mathrm{m} \text { en } \mathrm{mg} / \mathrm{min})\end{array}$ & $\begin{array}{l}\text { Surface of filtration } \\
\text { basin }\left(S \text { in } \mathbf{d m}^{2}\right)\end{array}$ & $\begin{array}{l}\text { Density of macrophytes } \\
\left(d \text { in plants } / \mathbf{m}^{2}\right)\end{array}$ & $\begin{array}{l}\text { Purifying capacity } \\
\text { (EH in population } \\
\text { equivalent) }\end{array}$ \\
\hline BCE & 50 & 253 & 0.20 & 104.6 & 10.56 & - & - \\
\hline BTP & 50 & 426 & 0.12 & 62.76 & 5.28 & - & - \\
\hline BTS & 50 & 761 & 0.07 & 36.61 & 12 & 75 & - \\
\hline SAUTEG & 50 & 1440 & 0.04 & 18.15 & 27.84 & 75 & 0.43 \\
\hline
\end{tabular}

BCE: Basin of Water Collection, BTP: Basin of Primary Treatment, BTS: Basin of Secondary Treatment, BET: Basin with Treated Water, min: minute

The data in the table have made it possible to dimension the system which extends over $9250 \mathrm{~cm}^{2}$ behind the laboratory of physical chemistry of the University of Abomey-Calavi.

- Two collection and pre-treatment basins (BCE1 and $\mathrm{BCE} 2)$ of $25 \mathrm{~L}$ each. They collect gray water at the entrance to the system at the inlet flow rate of $50 \mathrm{~L} / \mathrm{d}$.
- An anaerobic primary treatment (BTP) tank of $25 \mathrm{~L}$ to refine the decantation of the suspended matter. A secondary treatment tank (BTS) of $30 \mathrm{~L}$ consisting of three thick layers, respectively of: $6 \mathrm{~cm}$ for fine gravel or gravel $(\mathrm{Cg}), 1 \mathrm{~cm}$ for the low density polyurethane foam (CM1) which separates the $\mathrm{Cg}$ layer and The sandy one, which is $8 \mathrm{~cm}$ thick and is interposed with a 
foam (CM2) with respect to the gravel layer (CG) 10 $\mathrm{cm}$ thick. This basin is equipped with pipes (2 horizontal and 2 vertical) made of polyethylene $20 \mathrm{~mm}$ of diameter that drain water through the layers. The fine sand washed and dried twice for 15 days, the dimensions of which are $50 \mu \mathrm{m}$ to $2 \mathrm{~mm}$, contains plants pass through a second layer of $2 \mathrm{~cm}$ thick foam. The density of the Thalia geniculata plants in this filter basin, covered by coarse gravel, is 75 plants $/ \mathrm{m}^{2}$. The BTS basin is equipped with two sludge detectors, one at the inlet and the other at the outlet, which make it possible to check the level of sludge at the inlet and the outlet of the system in order to clean it. The aerators promote gas exchange $\left(\mathrm{O}_{2}, \mathrm{~N}_{2}\right.$ and $\left.\mathrm{H}_{2} \mathrm{~S}\right)$ at the matrix in the secondary treatment pond. The plants of Thalia geniculata absorb the pollutants contained in the gray waters through their rhizomes which serve as support for the microorganisms responsible for the degradation of the organic matter of the gray waters. Treated gray water passes through the entire system and is collected at the outlet of the facility in a treated water basin (BET). The model of the installed SAUTEG is shown in Figure 4.

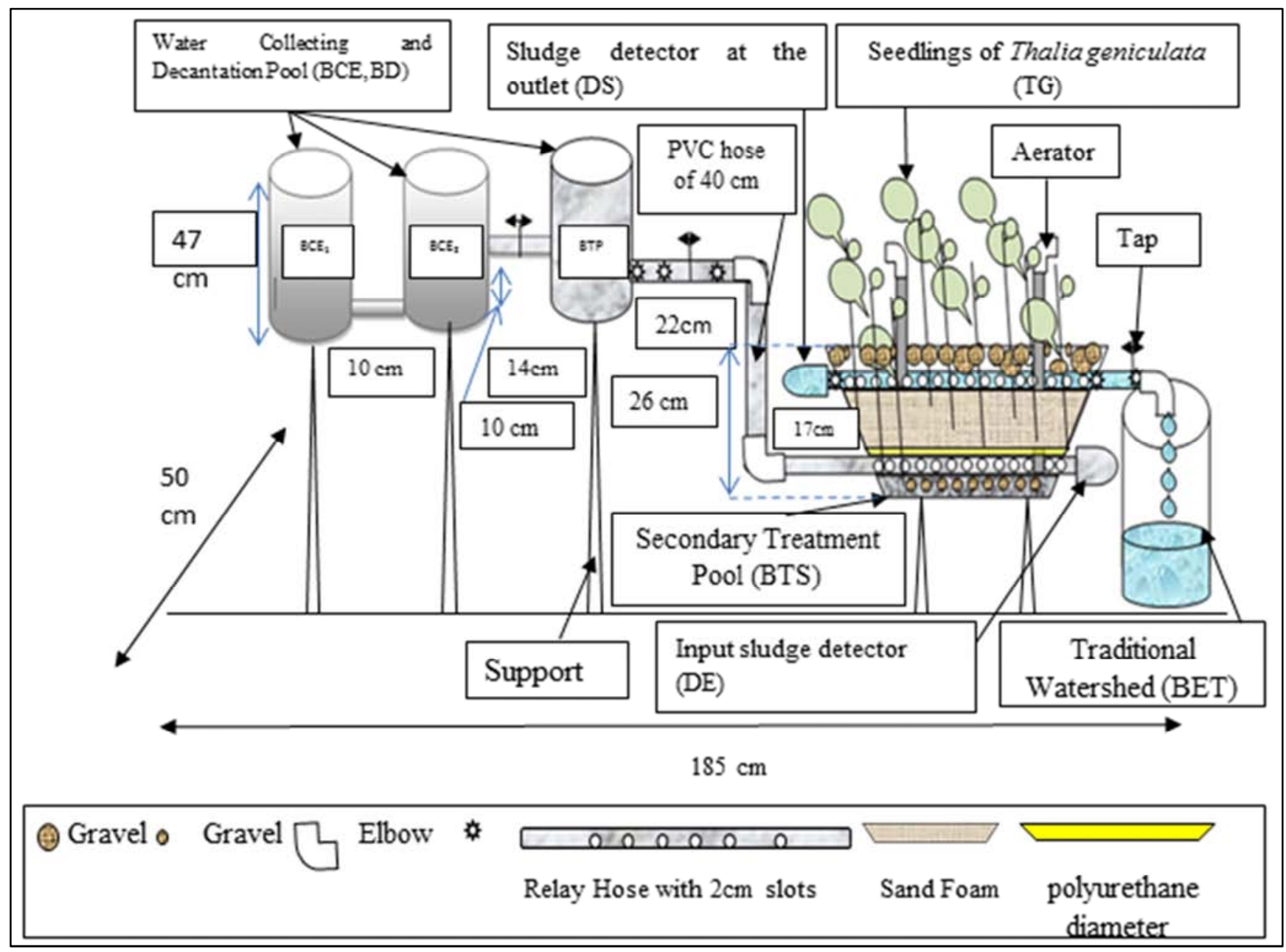

Figure 4. Autonomous Gray Water Treatment System (SAUTEG) model.

According to Allouche [11], plants can reach 4 plants $/ \mathrm{m}^{2}$ in a system. In our case we want to make the treatment faster and for this, three plants were placed in three rows with an interval between plants of $10 \mathrm{~cm}$ and then another interval of $5 \mathrm{~cm}$ between plants and walls of the filter pond. This makes a total of 9 plants of Thalia geniculata for an area of $1200 \mathrm{~cm}^{2}$ or a density of 75 plants $/ \mathrm{m}^{2}$. The constructive arrangement based on the flow and the organic load adopted by $[19,20]$ and Wallonia were useful for the design of the autonomous gray water treatment system (SAUTEG).

\subsubsection{System Flow Calibration (SAUTEG)}

The dimensioning was also based on the number of inhabitant equivalents (EH), the loss (D), the volumetric load $(\mathrm{y})$, and the chemical oxygen demand in five days $\left(\mathrm{BOD}_{5}\right)$. Calibration of the flow rate of the system led to the use of a shut-off valve R1 located between the collection basins BC and to settle BD placed on the half-turn. The $\mathrm{R} 2$ valve located between the settling pond and the secondary treatment tank BTS is set to one and a half turns. Finally, the tap located at the outlet and placed in a half-turn allows the treated water to be collected at an average flow rate equal to 
4.44.10 $10^{-1} \mathrm{~mL} / \mathrm{s}$ obtained after several tests which resulted in the figure of the calibration of the flow rate below.

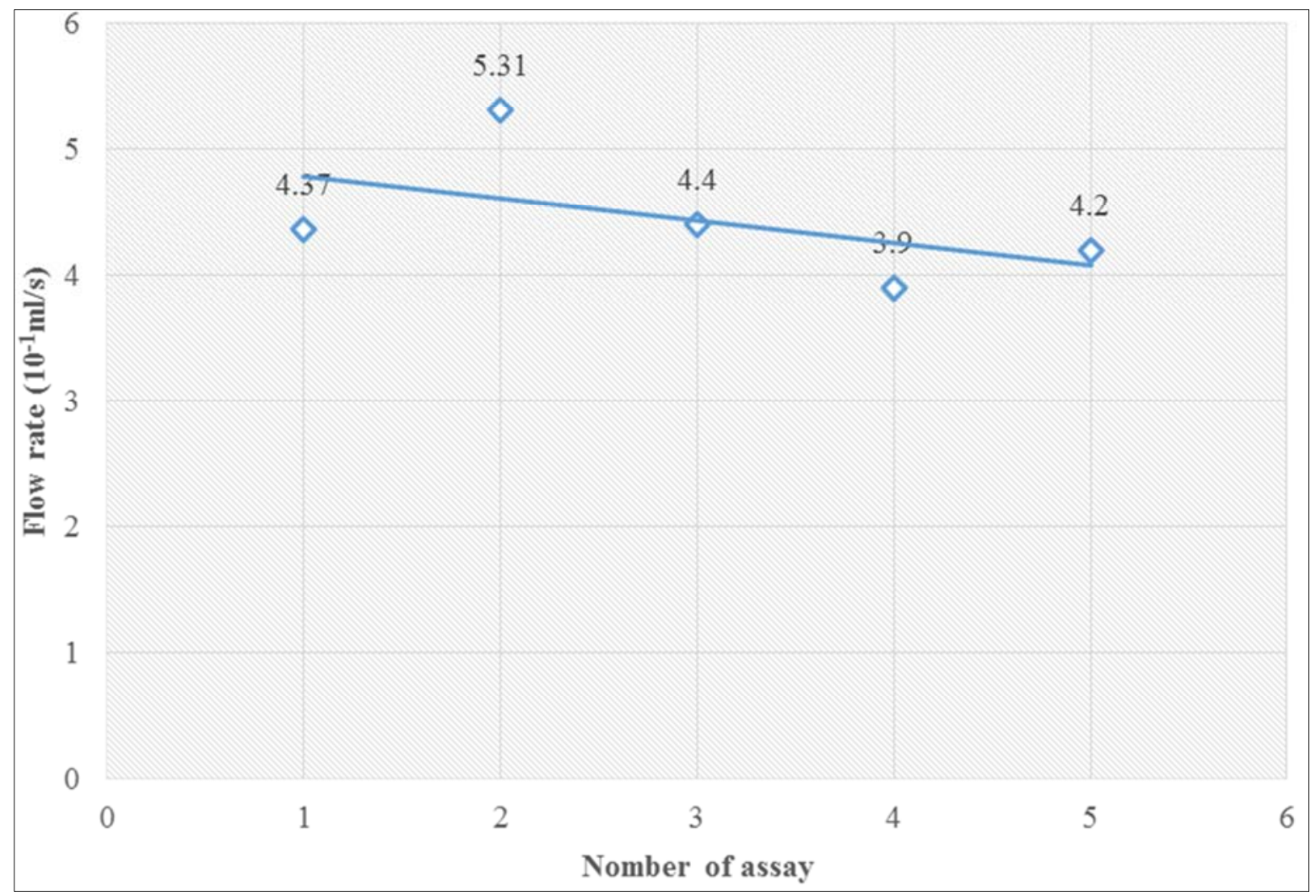

Figure 5. SAUTEG Flow calibration.

With an average flow rate of $4.44 .10^{-1} \mathrm{~mL} / \mathrm{s}$, the daily volume load $(\mathrm{Cv})$ defines 50 liters of treated wastewater per day $(50 \mathrm{~L} / \mathrm{d})$. Based on this volumetric load, the homogenizing parameter of the systems, the inhabitant equivalent (defined according to the European directive of 21 May 1991 as the biodegradable organic load having a $\mathrm{BOD}_{5}$ equal to $60 \mathrm{gO}_{2} / \mathrm{d}$ ) is determined according to the formula: BOD5 * 1/60. Hence, for our system $\left(\mathrm{BOD}_{5}: 523 \mathrm{mg} \mathrm{O} / \mathrm{d}\right.$ ), the purifying capacity obtained is 0.43 inhabitant equivalents and an organic charge equal to $26.15 \mathrm{~g} /$ day.

\subsection{Performance of the System}

\subsubsection{Physicochemical Parameters}

The table below (Table 2) shows the purification values and yields of some system monitoring parameters.

Table 2. Physicochemical parameters.

\begin{tabular}{lllllll}
\hline Parameters & EGo & EGT & Removal 1 & ECo & ECT & Removal 2 \\
\hline Cond $(\mu \mathrm{S} / \mathrm{cm})$ & 2458 & 558 & 77.30 & 1254 & 325 & 74.08 \\
Turb $(\mathrm{NTU})$ & 1176 & 69 & 94.13 & 123 & 14 & 88.62 \\
$\mathrm{TDS}(\mathrm{mg} / \mathrm{L})$ & 851 & 70 & 91.77 & 645 & 27 & 95.81 \\
$\mathrm{Coul}(\mathrm{Pt}-\mathrm{Co})$ & 7260 & 980 & 86.50 & 944 & 145 & 84.64 \\
$\mathrm{pH}$ & 8.6 & 7.07 & - & 6.4 & 7.04 & - \\
$\mathrm{O}_{2}(\mathrm{mg} / \mathrm{L})$ & 1.47 & 4.73 & - & 2.4 & 5.03 & - \\
$\mathrm{E}_{\mathrm{H}}(\mathrm{mV})$ & -8.2 & -5.2 & - & 1.8 & 2.4 & - \\
$\mathrm{RH}$ & 16.93 & 13.96 & - & 12.86 & 14.16 & - \\
$\mathrm{T}\left({ }^{\circ} \mathrm{C}\right)$ & 28.6 & 31.6 & - & 27.5 & 28.1 & - \\
\hline
\end{tabular}

The analysis of this table shows that the gray waters (EGo and $\mathrm{ECo}$ ) have $\mathrm{pHs}$ equal to 8.6 and 6.4, respectively before the treatment and then 7.07 and 7.04 after the treatment. So the waters which were basic and acid at the entrance of the system became almost neutral at the exit of the system. Therefore the ammonia which made the gray water EGo basic is reduced by treatment [21]. Similarly, the metal ions
$\left(\mathrm{Cd}^{2+}\right.$ and $\left.\mathrm{Pb}^{2+}\right)$, which could be responsible for the greywater acidity of the collector, have been eliminated in parts by the system [22]. Both treated gray water samples showed increased dissolved oxygen content (EGT: 4.73 $\mathrm{mg} / \mathrm{L}$, ECT: $5.03 \mathrm{mg} / \mathrm{L}$ ). This confirms the observations made by [23]. The redox potential of the effluents increases respectively from EGo to ECT while being less than $50 \mathrm{mV}$. 
Water samples produce fewer sulfides [24]. The oxidationreduction powers of effluents EGT, ECo and ECT are less than 15 and show that the medium is reducing. On the other hand, that of EGo (16.93) is comprised between 15 and 23, and suggests that EGo is favorable to the oxidation of organic matter [18]. Gray water temperatures range from $28^{\circ} \mathrm{C}$ to $32^{\circ} \mathrm{C}$. This shows that the experiments and sampling of water samples took place under the same climatic conditions. The contents between the inlet and the outlet of the system varied respectively from 2458 to $558 \mu \mathrm{S} / \mathrm{cm}$ for the electrical conductivity, 1176 to $69 \mathrm{NTU}$ for the turbidity; 851 to 70 $\mathrm{mg} / \mathrm{L}$ for TDS and 7260 to $980 \mathrm{Pt}-\mathrm{Co}$ for color, when treating the gray water (EG) of the sump. This gives respective removal efficiency of $77.29 \%, 94.13 \%, 91.77 \%$ and $86.50 \%$. For the gray waters of the Agla water collector (EC), similar reductions were obtained (Cond: $74.08 \%$, Turb: $88.61 \%$, TDS: $95.81 \%$ and Coul: $84.63 \%$ ). These purification yields were above $77 \%$ and make it possible to retain that the system significantly reduces the physicochemical parameters of the gray water (EG) of the sump, septic tanks and water collectors. The reductions obtained are close to or greater than those found by Toklo [25] (Turb: 95\%, TDS: $88.53 \%$ and Coul: 69.74\%) and Nougbodé [26] (Turb: 15\%).

\subsubsection{Abatement of Organic Load and Bacteria}

The histograms in the Figure 6 below show the percentages of organic charge abatements through $\mathrm{COD}$ and $\mathrm{BOD}_{5}$ and then those of bacteria through the E. coli, streptococci and fecal coli. Note that all histograms exceed $90 \%$ for both types of gray water. The COD elimination was $94 \%$ and $98 \%$, respectively, for $\mathrm{EG}$ and $\mathrm{EC}$. As for $\mathrm{BOD}_{5}$, it is also eliminated at $93 \%$ (EG) and $99 \%$ (EC). It can be said that the system has lowered the waters of the collector, less loaded than those of the sump, very loaded with organic matter. The system lowered the organic loads of the gray water with a remarkable performance for the waters of the collector of water, less loaded. These results support those reported by Vioget [27]. The histograms of the pathogenic bacteria or germs (E. coli, fecal streptococci and fecal coliforms) of the two gray waters showed purification yields close to $100 \%$. It can be deduced that the system effectively removed the bacterial flora of gray water regardless of their loads. The elimination of fecal coliforms in the SAUTEG system may be due to the combination of several conditions such as high temperature, UV radiation, dissolved oxygen, which in strong or low quantities are unfavorable to bacteria in anaerobic tanks BTP) $[28,29]$. These conditions can induce damage in the genetic material of the cells of these organisms indicative of bacterial pollution and thus prevent their reproduction, their survival and increasing their rate of elimination [29, 30]. Moreover, the large proliferation of macrophytes in the filter basin can contribute to the increase $[28,29]$ and the secretion of certain bactericidal substances [31]. The $\mathrm{pH}$ of greywater after treatment may favor the disappearance of fecal coliforms [32].
The shallow depth of the basins $(47 \mathrm{~cm})$ is an important parameter that can control the elimination of fecal coliforms from treated gray waters [9]. Indeed, one notices the abatement of bacterial germs was accompanied by a strong elimination of the organic matter. This relates to the statement of El Hachemi [31] which also notes an intimate relation between the elimination of organic matter and that of bacterial populations.

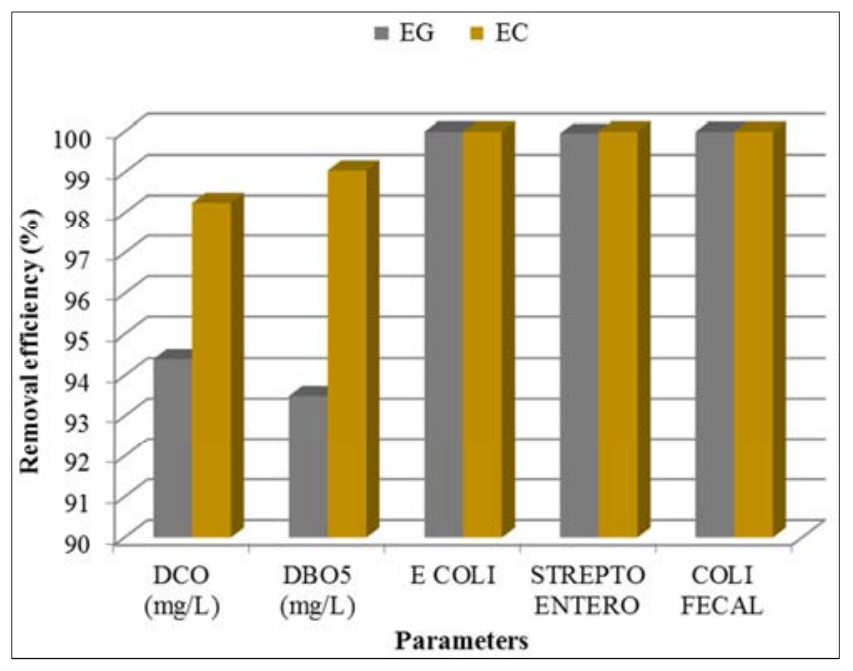

Figure 6. Abatement of organic load and bacteria.

\subsubsection{Abatement of Some Major Mineral Elements}

Figure 7 below shows the results of the purification efficiency of some major mineral elements, namely the suspended matter (MES, and the nutrients $\left(\mathrm{NO}_{3}^{-}, \mathrm{NTK}\right.$, $\mathrm{PO}_{4}{ }^{3-}$ ). $90 \%$ for gray water treated with a small shade in the collector water $\left(\mathrm{NO}_{3}{ }^{--}: 20 \%, \mathrm{PO}_{4}{ }^{3-}: 55,02 \%\right)$ and that of the sumps $\left(\mathrm{PO}_{4}{ }^{3-}: 14.69 \%\right)$, which have yields close to those of Allouche [11], TSS reductions (EGT: 99.99\%, ECT: 99.99\%), NTK (EGT: 96.46\%) show better performance of system $[33,34]$. This can be explained by the fact that these substances have been consumed by the macrophytes Thalia geniculata (Yovo et al., 2015). Low yields of orthophosphates may be due to their undissolved form in particulate form in gray water, which is poorly absorbable by macrophytes and is eliminated by chemical processes $[33,35,36]$. Comparison of the gray-water orthophosphate and nitrate ion contents shows that the ECo are more charged with $\mathrm{PO}_{4}{ }^{3-}(0.338 \mathrm{mg} / \mathrm{L})$ and $\mathrm{NO}_{3}{ }^{-}(4.2 \mathrm{mg} / \mathrm{L})$ ions compared to EGo $\mathrm{PO}_{4}{ }^{3-}(0.221 \mathrm{mg} / \mathrm{L})$ and $\mathrm{NO}_{3}{ }^{-}$ions $(2.81$ $\mathrm{mg} / \mathrm{L})$. This analysis shows that the high loading of the orthophosphate at the inlet of the system contributed to its acceptable abatement at the level of the EC but was not able to facilitate the removal of nitrates from the same water. The strong elimination of SS would be due to the different layers disposed in the filter treatment tank (BTS) [37]. From these results, it is noted that the SAUTEG system effectively reduced the contents of major mineral elements of the treated gray waters. 


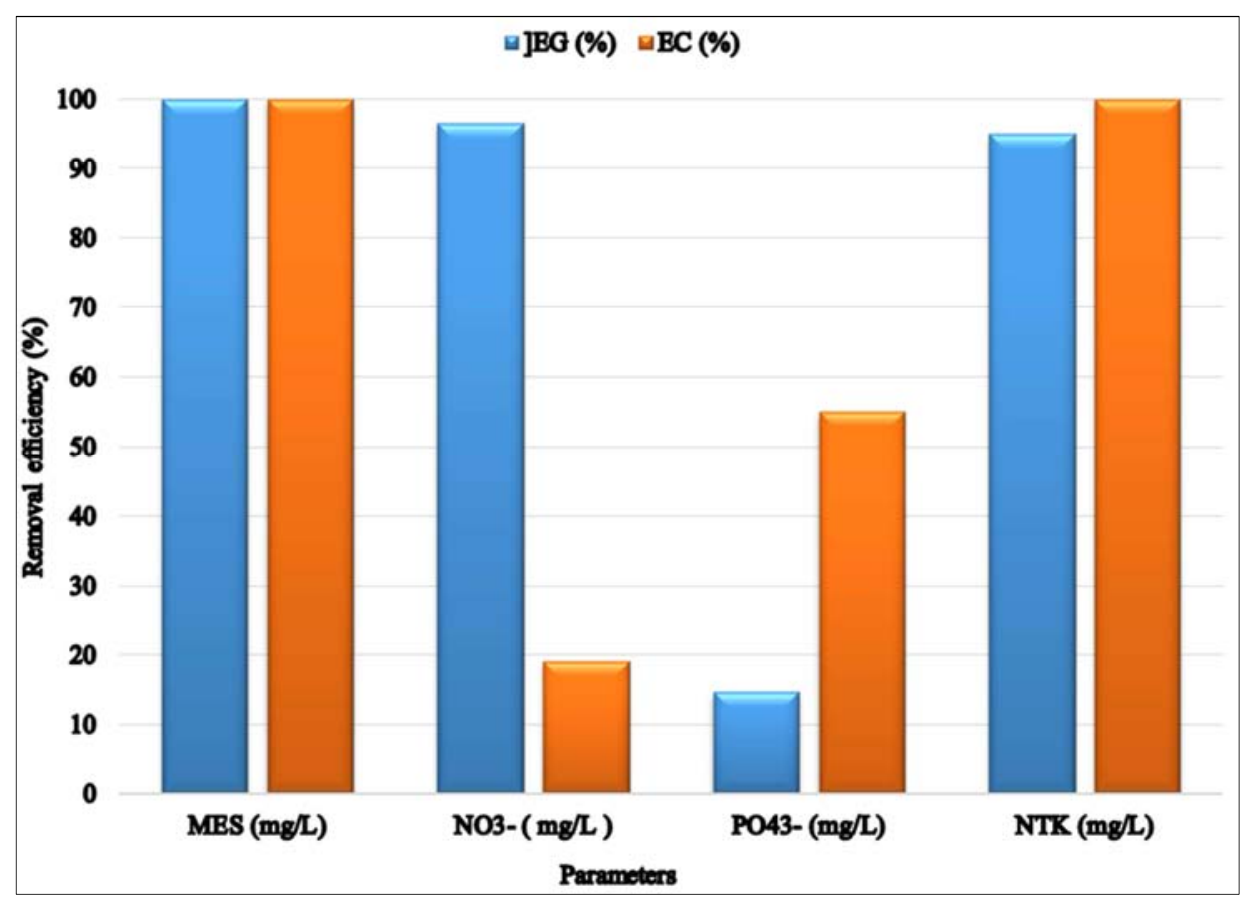

Figure 7. Abatement of some major mineral elements of treated gray water.

\subsubsection{Abatement of Some Micronutrients}

The evaluation of the purification performance of the system lead to the calculation of the purification yields of some trace elements of the treated gray water. For this purpose, the histograms made in Figure 8 show that, apart from the lead which was removed up to $87.02 \%$ in the collector water, that the other water purifying yields were lower than $25 \%$; the performance was evaluated at: EGT $(\mathrm{Pb}$ : $24.52 \%$, Cd: $11.84 \%$ ), ECT (Cd: $21.42 \%$ ). We noted a low abatement of these heavy metals by the system. This could be explained by the short residence time which did not allow the gray water metals to mineralize so that they become easily accumulated in the different vegetative parts of the macrophytes Thalia geniculate [38]. These yields of lead and cadmium were comparable to those obtained by Mc-Carthy [39]. It is noted that the collector receives a considerable amount of lead $(0.339 \mathrm{mg} / \mathrm{L})$ compared to gray water tanks $(0.212 \mathrm{mg} / \mathrm{L})$. The effective depletion of lead $(87.02 \%)$ in collector water may be related to the high mineralization of lead in this water. These results corroborate those of Giroud [37] and make it possible to retain that the heavy metals of highly mineralized waters would be easily reduced by the original gray water treatment system.

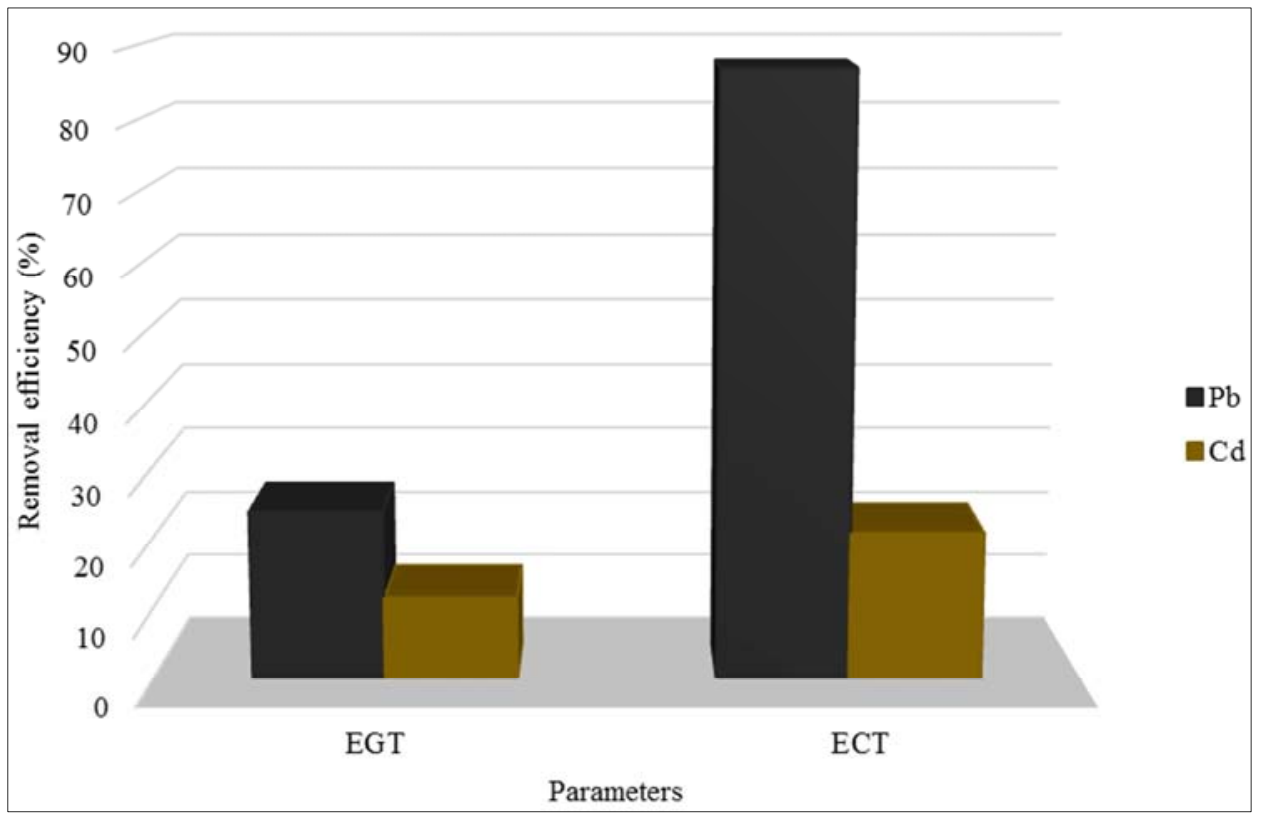

Figure 8. Abatement of some oligo-elements of treated gray water. 


\subsubsection{State of the Autonomous System of Treatment of Gray Water After Treatment}

The study of the state of the system was based on the organic load (Co), hydraulic load (CH), flux (F), volumetric load (CV), climb speed (VA) of sludge (P). The listed parameters can be found in the table below (Table 3).

Table 3. Status parameter of the autonomous gray water treatment system.

\begin{tabular}{|c|c|c|c|c|c|c|}
\hline Parameters & Co' (\%) & $\mathrm{C}_{\mathrm{H}}(\%)$ & F (mg/ day) & $\mathrm{Cv}\left(\mathrm{g} / \mathrm{dm}^{3} \cdot \mathrm{j}\right)$ & $V_{A}($ dm/day $)$ & $P(\mathrm{mg} /$ day $)$ \\
\hline & $* \mathrm{Co}^{\prime}=\frac{\mathrm{Cox} 100}{\mathrm{CN}}$ & ${ }^{*} \mathrm{C}_{\mathrm{H}}=\frac{\mathrm{Qx100}}{\mathrm{QN}}$ & $* \mathrm{~F}=\mathrm{PO}_{4} \mathrm{x} \mathrm{Q}$ & ${ }^{*} \mathrm{C}_{\mathrm{V}}=\frac{\mathrm{Co}}{\mathrm{VB}}$ & $* \mathrm{~V}_{\mathrm{A}}=\frac{\mathrm{Q}}{\mathrm{S}}$ & $* \mathrm{P}=0.8 \times \mathrm{DBO}_{5} \times \mathrm{Qxrend}^{\mathrm{a}}$ \\
\hline Formulas & $\begin{array}{l}{ }^{*} \mathrm{Co}=26.15 \mathrm{~g} / \mathrm{j} \\
{ }^{*} \mathrm{C}_{\mathrm{N}}=1000 \mathrm{~g} / \mathrm{j}\end{array}$ & $\begin{array}{l}* \mathrm{Q}=50 \mathrm{~L} / \mathrm{j} \\
{ }^{*} \mathrm{Q}_{\mathrm{N}}=80 \mathrm{~L} / \mathrm{j}\end{array}$ & $\begin{array}{l}* \mathrm{PO}_{4}=0.338 \mathrm{mg} / \mathrm{L} \\
{ }^{*} \mathrm{Q}=50 \mathrm{~L} / \mathrm{j}\end{array}$ & $\begin{aligned} * \mathrm{Co} & =26.15 \mathrm{~g} / \mathrm{L} \\
* \mathrm{~V}_{\mathrm{B}} & =40 \mathrm{~L}\end{aligned}$ & $\begin{array}{l}* \mathrm{Q}=50 \mathrm{~L} / \mathrm{j} \\
{ }^{*} \mathrm{~S}=12 \mathrm{dm}^{2}\end{array}$ & $\begin{array}{l}* \mathrm{DBO}_{5}=0.523 \mathrm{~g} / \mathrm{L} \\
* \mathrm{Q}=50 \mathrm{~L} / \mathrm{j} \\
* \text { rend }=0.99\left(\mathrm{DBO}_{5}\right)\end{array}$ \\
\hline SAUTEG & 52.3 & 62.5 & 16.875 & 16.76 & 4.16 & 1300 \\
\hline
\end{tabular}

a: yield of $\mathrm{BOD}_{5}$

The analysis of the table makes it possible to state that the realized system SAUTEG, has organic and hydraulic loads of more than $50 \%$. Therefore, it may contain a higher amount of organic filler. The flux and the volume loading are respectively equal to $16.87 \mathrm{mg} /$ day and $0.65 \mathrm{~g} / \mathrm{dm}^{3}$. The system can contain, in one day, a flux equal to $16.87 \mathrm{mg}$ of sludge and $0.65 \mathrm{~g} / \mathrm{dm}^{3}$ of treated wastewater. In our specific case, where $50 \mathrm{~L}$ of water has been treated, the system will contain a sludge load equal to $32.5 \mathrm{mg}$. Through this parameter, it is noted that the pipe connecting the primary tank (BCE2) to the settling tank (BTP) (primary treatment) can be clogged for a sludge load equal to $68.64 \mathrm{~g}$ in the BCE1 and BCE2 tanks. The climbing volume of the system was $4.16(\mathrm{dm} /$ day $)$ or $0.416 \mathrm{~m} /$ day and is much lower than that activated sludge $(0.6 \mathrm{~m} / \mathrm{h})$, for conventional stations. The sludge production $\mathrm{P}$ of our autonomous gray water treatment system (SAUTEG) was equal to $20.75 \mathrm{mg} /$ day. The total amount of sludge that the system can contain was $74.256 \mathrm{mg}$. This leads to a gross system service life of 3585.51 days (i.e 9 years and 300 days). The system's monitoring or status parameters allowed an idea of the lifetime and the loads that the system can contain.

\section{Conclusion}

This study allowed us to dimension an autonomous system of gray water treatment (SAUTEG) through a different methods recommended by Mara and Pearson, [20, 40]. Similarly, conventional and empirical methods have made it possible to use other parameters in the dimensioning of the system. The study of the purification performance of the SAUTEG system, based on the calculation of the purification yields of the various parameters, made it possible to note that the system considerably reduced certain physicochemical parameters, the organic load and then bacteria. Furthermore, major mineral elements and trace elements have been slaughtered in various ways and according to water loads. The low elimination of some pollutants may be related to their low mineralization, or to the short residence time of the macrophytes Thalia geniculata during treatment. The system status monitoring parameters permitted us to estimate approximately the sludge content, sludge load, and sludge saturation time of the system. This crucial information will be the subject of further study.

Table A1. Detail of studied parameters during the treatment process of wastewater.

\begin{tabular}{|c|c|c|c|c|c|c|}
\hline Parameters & EGo & EGT & Removal 1 EGT (\%) & ECo & ECT & Removal 2 ECT (\%) \\
\hline Cond $(\mu \mathrm{S} / \mathrm{cm})$ & 2458 & 558 & 77.29 & 1254 & 325 & 74.08 \\
\hline Turb (NTU) & 1176 & 69 & 94.13 & 123 & 14 & 88.61 \\
\hline TDS (mg/L) & 851 & 70 & 91.77 & 645 & 27 & 95.81 \\
\hline Coul (uca) & 7260 & 980 & 86.50 & 944 & 145 & 84.63 \\
\hline $\mathrm{pH}$ & 8.6 & 7.07 & 17.79 & 6.4 & 7.04 & -10 \\
\hline $\mathrm{O} 2(\mathrm{mg} / \mathrm{L})$ & 1.47 & 4,73 & -221.76 & 2.4 & 5.03 & 109.58 \\
\hline $\mathrm{E}_{\mathrm{H}}(\mathrm{mV})$ & -8.2 & -5.2 & 36.58 & 1.8 & 2.4 & -33.33 \\
\hline RH & 16.93 & 13.96 & 17.47 & 12.86 & 14.16 & -10.10 \\
\hline $\mathrm{T}^{\circ} \mathrm{C}$ & 28.6 & 31.6 & -10.48 & 27.5 & 28.1 & -2.18 \\
\hline MES (mg/L) & 405 & 0.022 & 99.99 & 158 & 0.005 & 99.99 \\
\hline $\mathrm{NO}_{3}^{-}(\mathrm{mg} / \mathrm{L})$ & 2.82 & 0.09 & 96.49 & 4.2 & 3.4 & 19.04 \\
\hline $\mathrm{PO}_{4}{ }^{3-}(\mathrm{mg} / \mathrm{L})$ & 0.21 & 0.18 & 14.69 & 0.338 & 0.152 & 55.02 \\
\hline NTK (mg/L) & 99 & 5 & 94.94 & 3 & 0 & 100 \\
\hline $\mathrm{DCO}(\mathrm{mg} / \mathrm{L})$ & 1445 & 80.8 & 94.40 & 1230 & 21.5 & 98.25 \\
\hline $\mathrm{DBO}_{5}\left(\mathrm{mg} \mathrm{O}_{2} / \mathrm{L}\right)$ & 523 & 34 & 93.49 & 421 & 4 & 99.04 \\
\hline $\mathrm{Pb}(\mathrm{mg} / \mathrm{L})$ & 0.21 & 0.16 & 24.52 & 0.339 & 0.044 & 87.02 \\
\hline $\mathrm{Cd}(\mathrm{mg} / \mathrm{L})$ & 0.076 & 0.067 & 11.84 & 0.098 & 0.077 & 21.42 \\
\hline Escherichia Coli (colonies) & 500000000 & 0 & 100 & 30000000 & 0 & 100 \\
\hline Streptococcus (colonies) & 140000 & 66 & 99.95 & 40000 & 0 & 100 \\
\hline Coli fecal (colonies) & 800000000 & 20000 & 99.99 & 600000000 & 12000 & 99.99 \\
\hline
\end{tabular}


Table A2. Different design methods used as inspiration for building our autonomous gray water treatment system (SAUTEG).

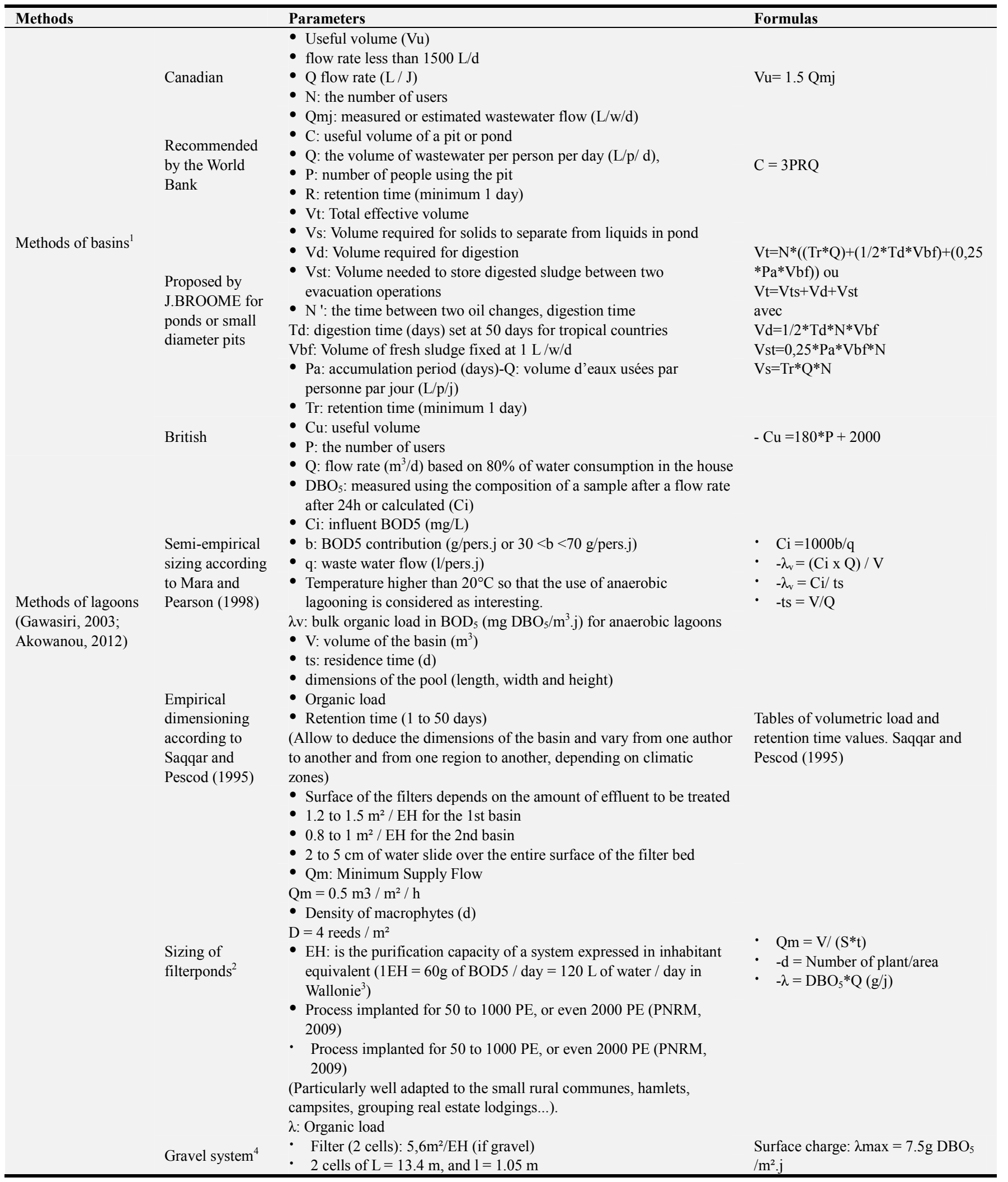

1http://www.oieau.fr/ReFEA/fiches/FossesSeptiques/FSmethodesDimensionnement8.pdf

2http://ec.europa.eu/environment/life/project/Projects/index.cfm?fuseaction=home.showFile\&rep=file\&fil=LIFE_Ruisseaux_Guide_Methodo.pdf

3clusters.wallonie.be/servlet/.../ficheepuvaleau012007-2-21694.pdf?ID.

4http://www.epuval.eu/EPUVAL/Lesprincipauxchiffresaretenir.pdf 


\begin{tabular}{lll}
\hline Methods & Parameters & Formulas \\
\hline & $60 \mathrm{~cm}$ of gravel and non-calcareous roller of which $54 \mathrm{~cm}$ are sub- & -He: level of wastewater / day on the \\
& water (Phragmitesaustralis or communis of density of $5 \mathrm{plants} / \mathrm{m}^{2}$ ) & whole filter (Approximately $20 \mathrm{~L}$ of \\
& use of a pump with a difference in height (D) less than $28 \mathrm{~cm}$ & wastewater/ $\mathrm{m}^{2}$. day for an equal \\
& between the arrival of the waste water and the discharge & level $2 \mathrm{~cm}$ ) \\
\hline
\end{tabular}

\section{References}

[1] PNUD. Rapport sur le Développement Humain Durable de l'Afrique, 82 p, 2004.

[2] C. Tchakpa. Valorisation des déchets solides ménagés comme alternative à l'utilisation des engrais chimiques de synthèse dans le maraichage à Cotonou, Thèse pour l'obtention du grade de docteur de l'Université d'Abomey-Calavi, $128 \mathrm{p}$, 2015.

[3] N. Poiret. Odeurs impures, du corps humain à la cité (Grenoble, XVIIIe XIXe siècle), Terrain Anthropologie \& sciences humaines, Collection Ethnologie de la France, Cahiers d'ethnologie de la France, pp 89-102, septembre 1998.

[4] E. U. R. Ouedraogo. La gestion urbaine dans les pays du sud, DEA Université de Ouagadougou, 2010.

[5] Y. Kafando. Environnement urbain et problèmes de santé à Ouagadougou, Mémoire de Maîtrise: cas du quartier Cissin, 2003/2004.

[6] L. Monjour. Les pathologies d'origine hydrique et la potabilité de l'eau; Les Cahiers du MURS n³3 - 2ème trimestre 1997.

[7] A. Robert. Méthodes de lutte contre les moustiques pour les particuliers, Département de biologie, Université de Winnipeg, 2003.

[8] S. Neubert, S. Benabdallah. La réutilisation des eaux usées traitées en Tunisie, Etude et rapport d'expertise, Institut Allemand de Développement, 11/2003.

[9] O. EL Hachemi. Traitement des eaux usées par lagunage naturel en milieu désertique (Oasis de Figuig): performances épuratoires et aspect phytoplanctoniques, Thèse présentée à la Faculté pour obtenir le grade de Docteur, Production végétale Spécialité: Ecologie végétale UFR, Novembre 2012.

[10] F. Miss. Etude des possibilités de valorisation des produits issus de traitement des boues de vidange: cas de Yaoundé, Cameroun, Ecole Nationale d'Enseignement Supérieur d'Agronomie de Dijoin, CREPA Cameroun, p 142, 2007.

[11] N. F. Allouche. La phytoremédiation pour la dépollution des eaux usées, Bulletin des Energies Renouvelables, $\mathrm{N}^{\circ} 10$, décembre 2006.

[12] CIE. L'assainissement des eaux usées, Janvier 2016.

[13] S. Moulin, D. Rozen-Rechels, M. Stankovic. Traitement des eaux usées; atelier l'eau Qualité vs Quantité; 1 er semestre Année 2012-2013.

[14] A. San Miguel. Phytoremédiation des organochlorés. Etude mécanistique et fonctionnelle des capacités épuratrices du système plante-rhizosphère, Thèse pour obtenir le grade de Docteur de l'université de Grenoble, décembre 2011.

[15] ENSA. Les macrophytes aquatiques bio indicateurs des systèmes biologiques. Intérêts et limites des indices microphysiques, Synthèse bibliographique des principales approches européennes pour le diagnostic biologique des cours d'eau. Octobre 2001.

[16] IFREMER. La surveillance FOGEM des zones humides côtières du Languedoc-Roussillon 2000-2005.

[17] M. P. Aina, N. M. Kpondjo, J. Adounkpe, D. Chougourou, M. Moudochirou. Study of the purification efficiencies of theirfloating macrophytes in wastewater treatment, Research Journal of chemical Sciences; Vol. 1 (3), pp. 2319-1414. Facultés des sciences et Techniques de l'eau de l'Ecole Polytechnique d'Abomey- calavi, Université d'Abomey Calavi, Octobre 2012.

[18] A. V. O. Akowanou. Phytoépuration des eaux usées domestiques: Evaluation des paramètres de performances par combinaison de trois macrophytes flottants. 2012.

[19] K. R. Effebi. Lagunage anaérobie: modélisation combinant la décantation primaire et la dégradation anaerobie, Thèse de doctorat en sciences, 2009.

[20] D. D. Mara \&H. W. Pearson. Design manual for waste, W. H. O., Regional Office for Europe. 104pp, 1998.

[21] G. Deronzier, S. Schétrite, Y. Racault, J. P. Canler, A. Liénard, A. Héduit, P. Duchène, "Traitement de l'azote dans les stations d'épuration biologique des petites collectivités", Document technique FNDAE, n²5, 2001.

[22] M. Larakeb, L. Youcef, A. Achour. Effet de différents paramètres réactionnels sur l'élimination du zinc par adsorption sur la bentonite de Mostaghanem et sur le kaolin, Université Mohamed Khider - Biskra, Algérie, Courrier du Savoir - Nº19, pp. 49-54, Mars 2015.

[23] G. Deviller. Traitement par lagunage à haut rendement algal (LHRA) des effluents piscicoles marins recyclés: Evaluation chimique et écotoxicologique, Thèse pour l'obtention de grade de docteur de l' Université de Montpellier I, 172 p, novembre 2003.

[24] F. Resjek. Analyse des eaux: aspects réglementaires et techniques. Coll. Biologie technique. Science et technique de l'environnement, 360p, 2002.

[25] M. R. Toklo, R. G. Josse, N. Topanou, A. F. C. Togbé, P. Dossou- Yovo, B. Coulomb. Caractérisation physicochimique des lixiriats d'une d'échange: cas du lieu d'enfouissement sanitaire de Oussè - Ouidah (Sud Bénin), International Journal of Innovation and Applied Studies, Vol 13, No; pp. 921-928, Décembre 2015.

[26] A. E. I. Nougbode, P. Sessou, A. K. Youssao, C. P. Agbangnan, D. Mama, K. C. D. Sohounhloue. Évaluation de gel d'Aloevera en feuilles comme un floculant naturel: criblage phytochimique et élimination de la turbidité des essais d'eau par coagulation floculation, Res. J. Sci., 5 (1), 9$15,2016$.

[27] P. Vioget, C. A. Jacquered, E. Ruegg. Bilan de l'épuration vaudoise, Département de la sécurité et de l'environnement (DES); service eaux, sols et assainissement, 2011. 
[28] H. W. Pearson, D. D. Mara, S. W. Mills \& D. L. Smallman. Factors determining algal population in waste stabilization ponds and the influence of algae on pond performance. Wat. Sci. Tech. 19 (12): 131-140, 1987.

[29] D. O. Olukanni\&J. J. Ducoste. Optimization of waste stabilization ponds for developing nations using computation fluid dynamics, Ecological Engineering, 37: 1878-1888, 2011.

[30] M. Er. El Hachemi. Association de l'Ozone, des ultraviolets et des ultrasons pour le traitement d'effluents à forte charge organique, Thèse de Doctorat, Ecole Supérieure d'Ingénieurs de Chambéry, Université de Savoie, 135 p, 2005.

[31] O. El Hachemi, H. El Halouani, M. Meziane, A. Torrens, M. Salgot, M. SBAA. Etude des performances épuratrices dans une station de traitement des eaux usees par lagunage en climat désertique (Oasis de Figuig - Maroc): aspect bactérien et organique, Rev. Microbiol. Ind. San et Environn. Vol 6, $\mathrm{n}^{\circ} 1$, p: 84-97, 2012.

[32] C. Volk. Contrôle de la matière organique biodégradable au cours des traitements d'oxydation et de la distribution des eaux d'alimentation. Hydrologie. Ecole Nationale des Ponts et Chaussées, 1994.

[33] R. Gourdon, M. Kanita, M. Gautier, B. Kimi, P. Mickel. Traitement des eaux usées domestiques par une installation de filtres de roseaux à écoulement vertical $\mathrm{C}, \mathrm{N}, \mathrm{P}$ et micropolluants, Colloque International E3D, Lomé, 2016.
[34] DRELB (Direction Régionale de l'Environnement et du Logement Bretagne). Etude d'impact du traitement des effluents urbains, Fiche de cadrage de l'autorité environnementale, 2012.

[35] F. Yovo, B. Dimon, C. E. Azandegbe, F. Suanon, E. Sagbo, D. Mama, M. Aina. Phytoremediation: Investigation and valorization of purifying power of Thalia geniculatain for domestic wastewater treatment, Research Journal of Chemical Sciences, Vol. 5(12), 1-6, December 2015.

[36] F. Yovo, B. Dimon, F. Suanon, C. E. Azandegbe, I. Agani, V. Wotto. Phytoremediation: Synergistic Effect of Thalia geniculata and Crassipes Eichhornia (Water Hyacinth) During Domestic Wastewater Treatment, Plant. 5 (1): 1-8.

[37] V. Giroud. Les filtres plantés de roseaux pour le traitement des eaux pluviales, 2007

[38] S. Yapoga, Y. B. Ossey, V. Kouamé. Phytoremediation of zinc, cadmium, copper and chrome from industrial wastewater by Eichhornia crassipes, International Journal of Conservation Science, Volume 4, Issue 1,: 81-86, January-March 2013.

[39] J. J. Mc-Carthy, D. Wynne, T. Berman. The uptake of dissolved nitrogenous nutrients by lake Kinneret (Israel) microplancton, Limnol. Oceanogr. 27: 673-680, 1983.

[40] M. M. Saqqar, M. B. Pescod. Modelling the performance of anaerobic wastewater stabilization ponds, Water Science and Terchnology, vol.31 (12): 171-183, 1995. 